BIOMEDICAL AND BIOSOCIAL ANTHROPOLOGY
$\begin{gathered}\text { Official Journal of the International Academy } \\ \text { of Integrative Anthropology } \\ \text { journal homepage: http://bba-journal.com }\end{gathered}$

\title{
Actual aspects of traumatic pathology among servicemen of Ukrainian Armed Forces in Joint Forces Operation
}

\section{Halushka A. M. ${ }^{1}$ Khalik S. V. ${ }^{1}$, Rychka O. V. ${ }^{2}$ Lopin Ye. B. ${ }^{2}$}

${ }^{1}$ Ukrainian Armed Forces, Medical Forces Command, Kyiv, Ukraine

${ }^{2}$ Ukrainian Military Medical Academy, Research Institute of Military Medicine, Kyiv, Ukraine

\section{ARTICLE INFO}

Received: 2 November 2020

Accepted: 1 December 2020

UDC: $614.2: 616-$

001:356.33:355.721:355/359.08

\section{CORRESPONDING AUTHOR}

e-mail: galushka_a@i.ua Halushka A. M.
The use of these traditional peacetime methodological approaches to accounting and analysis of non-combat injuries has led to an underestimation of its high level in the planning of inpatient care for servicemen of the Armed Forces of Ukraine in the area of the Joint Forces operation (anti-terrorist operation). The purpose of the study is a general assessment of the place of combat and non-combat injuries (including poisoning) in the structure of cases of hospitalization of servicemen of the Armed Forces of Ukraine in the area of the Joint Forces operation and anti-terrorist operation. Statistical mathematical processing was performed using computer programs Microsoft Excel and STATISTICA (version 6, StatSoft, Inc.). Based on annual medical reports on $3 /$ med form, the ICD-10 structure of Ukrainian Armed Forces servicemen treated in MTF located in area of Joint Forces Operation for 2015-2020 has been presented. Ranks of disease classes have been calculated. Based on medical reports according Temporary instruction on codification of battle injures, non-battle trauma and diseases in Ukrainian Armed Forces, the structure of casualties admissions to MTF have been pointed out. The leading places in structure of treated servicemen belongs to patients with diagnoses on XIX class of ICD-10 (1 ${ }^{\text {st }}$ place for 2015-2019, $2^{\text {nd }}$ place in 2020) that was stipulated by relative high levels of non-battle trauma in troops on the East of Ukraine. The comparison of structure of servicemen treated in MTF located in and out area of Joint Forces Operation as well as with structure of adult population (over 18 years old) treated in civil hospitals has been conducted. Prevalence of traumatic pathology levels among patients treated in MTF located in area of Joint Forces Operation in comparison with others treatment facilities data has been revealed. For 2015-2020 the shares of trauma and poison cases in structure of treated servicemen in MTF located in area of Joint Forces Operation significantly decreased that was connected with gradual lowing of battle actions intensity and non-battle trauma level. Based on result of research the necessity to improve curative and diagnostic base of military treatment facilities in area of Joint task operation as well as medical report and nonbattle trauma prevention systems has been concluded.

Keywords: non-battle trauma, structure of treated patients, servicemen of the Armed Forces of Ukraine (anti-terrorist operation), Joint Forces Operation, military mobile hospitals.

\section{Introduction}

The share of traumatic pathology in the structure of treated patients is an important indicator that determines the activities of health care facilities of the Armed Forces of Ukraine due to the fact that treatment of injuries is high, requires modern medical and diagnostic equipment and significant costs of material, technical and human resources [3].

The system of collecting medical static data and methodological approaches used for their analysis in the medical service of the Armed Forces of Ukraine do not allow to fully assess the impact of injuries among servicemen of the Armed Forces of Ukraine on the work of military medical facilities in the area of JFO (anti-terrorist operation). In particular, the statistical observations focused primarily on the structure of injuries, namely, mainly studied their structure by location, as well as the causes and 
circumstances of injuries [3, 4, 19].

As a result of using these traditional methodological approaches in peacetime to the accounting and analysis of non-combat injuries led to an underestimation of its high level during the planning of inpatient care for servicemen of the Armed Forces of Ukraine in the area of the Joint Forces operation (anti-terrorist operation) which determined the relevance of this study.

The purpose of the study is a general assessment of the place of combat and non-combat injuries (including poisoning) in the structure of cases of hospitalization of servicemen of the Armed Forces of Ukraine in the area of the Joint Forces operation and anti-terrorist operation.

\section{Materials and methods}

The source of data on the magnitude, circumstances and causes of injuries of servicemen of the Armed Forces of Ukraine in the area of the Joint Forces operation (antiterrorist operation) (hereinafter - JFO and ATO, respectively) were reports provided by health facilities of the Armed Forces of Ukraine under the Interim Instruction codification of combat injuries, non-combat injuries and diseases in the Armed Forces of Ukraine, approved by the order of the Director of the Military Medical Department of the Ministry of Defense of Ukraine dated 28.12.2016 № 37 (hereinafter the Temporary Codification Instruction).

The source of data on the structure of treated patients in mobile military hospitals were medical reports in the form of 3/Med, which until 2017 were provided in the form of certain reports, and from 2017 - according to the orders of the governing body implementing the state policy in the Armed Forces in the field of health care of servicemen, members of their families and other categories of citizens defined by the legislation of Ukraine (currently it is the Command of the Medical Forces of the Armed Forces of Ukraine, hereinafter - the CMF) [5].

Statistical analysis of available research materials was performed using standard methods of mathematical statistics. Statistical mathematical processing was performed using computer programs Microsoft Excel from Microsoft Office and STATISTICA (version 6, StatSoft, Inc.).

\section{Results}

Despite a certain decrease in the number of cases of hospitalization of servicemen due to non-combat injuries in the area of JFO/anti-terrorist operation during 2015-2020, its level remains relatively high, especially considering that in most cases injuries of servicemen are related to human factors. can potentially be prevented through preventive measures. We found that the ratio of combat injuries to non-combat injuries among servicemen - members of the ATO (JFO) in 2017 was - 1: 1.19; 2018 - 1: 1.36; 2019 - 1: $1.33 ; 2020-1: 1.57$, which indicates the need to pay more attention to the prevention of non-combat injuries in the inter-combat period.

Next, we analyze the place of injuries in the general structure of hospitalizations in health care facilities of the Armed Forces of Ukraine in the area of JFO (ATO), which gives grounds to emphasize the need to improve the existing system of medical accounting and reporting, as well as the need to improve logistics Forces of Ukraine.

Our calculated structure of servicemen of the Armed Forces of Ukraine, treated during 2015-2020 in military hospitals stationed in the area of the Joint Forces operation (anti-terrorist operation), indicates that during 2015-2019 the first place in the structure of treated military patients diagnosed with class XIX ICD-10 "Injuries, poisoning and some other consequences of external causes" (35.39\%, $27.39 \%, 26.44 \%, 22.55 \%$ and $17.12 \%$ respectively), the second - class $X$ diseases "Respiratory diseases" (13.54 $\%, 20.14 \%, 16.64 \%, 16.98 \%$ and $16.96 \%$ respectively). Only in 2020, class $X$ diseases in the structure took the traditional 1st place $(18.21 \%)$, pushed to 2nd place class XIX $(16.06 \%)$. In this case, according to Fisher's transformation criterion (see [1]), the proportion of patients in class XIX differed significantly from the proportion of patients in class $X(p<0.001)$.

Regarding other classes of diseases, in different years 3,4 and 5 rank place in different combinations in the structure of treated servicemen was occupied by diseases of XI class "Digestive diseases", XIII class "Diseases of the musculoskeletal system and connective tissue" and IX class "Diseases of the circulatory system."

At first glance, it is thought that injuries and poisonings occupy such an important place in the structure of treated patients as a result of admission to hospitals stationed in the area of JFO (ATO) wounded during hostilities related to combat casualties. But according to reports provided under the Provisional Instruction on Codification, the XIX class took first place in the structure largely due to cases of hospitalization of servicemen who received non-combat injuries.

It should be noted that the share of servicemen of the Armed Forces of Ukraine hospitalized for non-combat injuries decreased more than 2 times: from $17.36 \%$ in 2017 to $7.99 \%$ in 2020 (Table 1).

If we compare the obtained statistics with the structure of classes ICD-10 servicemen treated in other health care facilities of the Armed Forces of Ukraine, and the structure of adult patients (aged 18 and older) who left the hospitals of health care facilities of Ukraine [11-16], you can see the following (Table 2):

the share of servicemen treated in military hospitals stationed outside the area of JFO (ATO), whose diagnoses belong to the XIX class of diseases, took in 2015 2nd place, in 2016 - 4th place, in 2017-2020 - 5th rank (in the general structure for all classes of diseases);

the share of patients treated in civilian health care facilities of Ukraine, whose diagnoses belong to the XIX class of diseases, took a stable 7th place during 20152020.

The estimation of the tendency of change of the share 
Table 1. The structure of the inflow of patients to military hospitals in the area of the Joint Forces operation (anti-terrorist operation) in eastern Ukraine by categories of sanitary losses for the period 2017-2020, \%.

\begin{tabular}{|l|c|c|c|c|c|c|c|c|c|c|c|c|}
\hline \multirow{2}{*}{ Health institution } & \multicolumn{4}{|c|}{$\begin{array}{c}\text { Combat defeat (injury, } \\
\text { wounding) }\end{array}$} & \multicolumn{3}{c|}{ Non-combat trauma * } & \multicolumn{4}{c|}{ Disease } \\
\cline { 2 - 14 } & 2017 & 2018 & 2019 & 2020 & 2017 & 2018 & 2019 & 2020 & 2017 & 2018 & 2019 & 2020 \\
\hline $59 \mathrm{MMH}$ & $* *$ & 9.28 & 5.62 & 6.35 & $* *$ & 12.12 & 7.64 & 8.17 & $* *$ & 78.60 & 86.74 & 85.48 \\
\hline $66 \mathrm{MMH}$ & 16.54 & 9.18 & 6.63 & 6.14 & 15.55 & 12.72 & 11.53 & 8.45 & 67.91 & 78.10 & 81.85 & 85.40 \\
\hline $65 \mathrm{MMH}$ & 16.25 & 7.11 & 7.54 & 3.88 & 23.12 & 9.75 & 6.72 & 7.72 & 60.63 & 83.13 & 85.75 & 88.40 \\
\hline $61 \mathrm{MMH}$ & 8.46 & 10.08 & 8.08 & 5.42 & 11.39 & 13.20 & 11.58 & 8.86 & 80.15 & 76.72 & 80.34 & 85.71 \\
\hline $450 \mathrm{MH}$ & 6.36 & 0.40 & - & - & 4.65 & 3.95 & - & - & 89.00 & 95.65 & - & - \\
\hline $385 \mathrm{MH}$ & 25.00 & 0 & 11.54 & 0 & 25.00 & 0 & 50.00 & 0 & 50.00 & 100 & 38.46 & 100 \\
\hline $\begin{array}{l}\text { Military Medical Clinical Center of the } \\
\text { Northern Region (Kharkiv) }\end{array}$ & 6.01 & 0 & 3.53 & 2.38 & 1.91 & 0 & 0.59 & 1.02 & 92.08 & 100 & 95.88 & 96.60 \\
\hline $555 \mathrm{MH}$ & - & - & - & 1.07 & - & - & - & 9.01 & - & - & - & 89.91 \\
\hline All institutions & 14.63 & 8.39 & 6.87 & 5.09 & 17.36 & 11.38 & 9.13 & 7.99 & 68.01 & 80.24 & 84.00 & 86.92 \\
\hline
\end{tabular}

Notes: ${ }^{*}$ - the following groups of diagnoses of the XIX class were carried to diseases: poisoning by medicines and biological substances. (T36-T50); toxic effects of substances, mainly non-medical purposes (T51-T65); other and unspecified effects of external causes (T66-T78); complications of surgical and therapeutic interventions, which are not classified in other headings (T80-T88); consequences of injuries, poisonings and other influences of external causes (T90-T98); ** - in the report $59 \mathrm{MMH}$ for 2017 cases of hospitalization for diseases were not presented.

Table 2. The structure of patients in certain classes of ICD-10, discharged from hospitals of health care institutions for the period 2015$2020, \%$.

\begin{tabular}{|c|c|c|c|c|c|c|c|c|c|c|c|c|c|}
\hline \multirow[t]{2}{*}{ Classes of diseases } & \multirow{2}{*}{$\begin{array}{l}\text { Codes } \\
\text { according } \\
\text { to ICD-10 }\end{array}$} & \multicolumn{6}{|c|}{$\begin{array}{l}\text { The structure of patients of all categories who } \\
\text { left the civilian health care facilities of Ukraine }\end{array}$} & \multicolumn{6}{|c|}{$\begin{array}{l}\text { Structure of servicemen who left military } \\
\text { hospitals (excluding JFO facilities) }\end{array}$} \\
\hline & & 2015 & 2016 & 2017 & 2018 & 2019 & 2020 & 2015 & 2016 & 2017 & 2018 & 2019 & 2020 \\
\hline $\begin{array}{l}\text { Class V. Mental and behavioral } \\
\text { disorders }\end{array}$ & F00-F99 & 4.29 & 4.31 & 4.34 & 4.55 & 4.54 & 4.83 & 5.43 & 4.29 & 4.85 & 5.33 & 4.85 & 3.96 \\
\hline $\begin{array}{l}\text { Class IX. Diseases of the } \\
\text { circulatory system }\end{array}$ & $100-199$ & 22.12 & 22.05 & 22.75 & 22.80 & 23.19 & 19.94 & 10.74 & 10.65 & 12.13 & 13.09 & 13.87 & 15.42 \\
\hline $\begin{array}{l}\text { Class } X \text {. Diseases of the } \\
\text { respiratory system }\end{array}$ & J00-J99 & 8.35 & 9.29 & 8.14 & 8.23 & 8.04 & 11.89 & 22.48 & 26.41 & 23.16 & 22.40 & 22.39 & 24.51 \\
\hline $\begin{array}{l}\text { Class XI. Diseases of the } \\
\text { digestive system }\end{array}$ & K00-K93 & 9.35 & 9.09 & 9.29 & 9.22 & 9.07 & 8.71 & 9.56 & 10.01 & 10.27 & 9.98 & 10.03 & 8.97 \\
\hline $\begin{array}{l}\text { Class XIII. Diseases of the } \\
\text { musculoskeletal system }\end{array}$ & M00-M99 & 6.35 & 6.21 & 6.32 & 6.45 & 6.53 & 4.87 & 10.47 & 10.08 & 11.67 & 11.75 & 11.71 & 10.03 \\
\hline $\begin{array}{l}\text { Class XIX. Injuries and } \\
\text { poisoning }\end{array}$ & S00-T98 & 7.10 & 7.10 & 7.12 & 6.94 & 6.81 & 6.73 & 16.48 & 10.03 & 8.73 & 7.46 & 7.04 & 7.06 \\
\hline
\end{tabular}

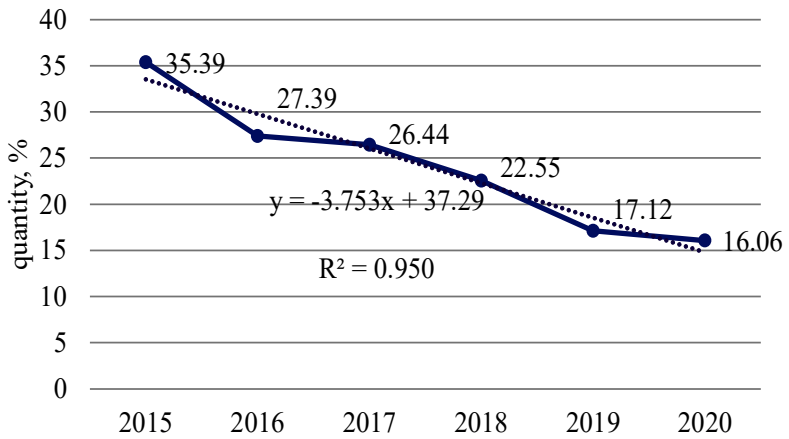

Fig. 1. Assessment of the trend of changes in the proportion of patients hospitalized in health care facilities of the Armed Forces of Ukraine in the area of JFO/ATO for pathological conditions belonging to the XIX class of diseases according to ICD-10. of patients hospitalized to the health care institutions of the Armed Forces of Ukraine in the area of JFO (ATO) concerning pathological conditions belonging to the $\mathrm{XIX}$ class of diseases according to ICD-10 is given in Fig. 1 .

As can be seen from Fig. 1, the share of patients with pathology classified as class XIX diseases decreased annually by an average of $15.12 \%$, which can be explained by the implementation of a set of measures to implement the Minsk agreements in eastern Ukraine, as well as the introduction of a ceasefire on July 27, 2020.

This was due to a correlated decrease in the proportion of servicemen hospitalized with combat injuries (wounds, injuries) and servicemen hospitalized for non-combat injuries (correlation coefficient $R=0.997, p<0.001$ ). 


\section{Discussion}

The system of injury prevention in the Armed Forces of Ukraine needs further improvement, in particular, in our opinion, the system of medical accounting and reporting of casualties of the Armed Forces of Ukraine needs to be revised.

Thus, in the classifications of types of losses of personnel of the Armed Forces of Ukraine, given in the Instruction on medical support of the Armed Forces of Ukraine for a special period [9], approved by the order of the General Staff of the Armed Forces of Ukraine from 11.02.2019 № 60, and Methodical manual personnel of the Armed Forces of Ukraine [8], approved by the Chief of the General Staff - Commander-in-Chief of the Armed Forces of Ukraine on October 29, 2019, non-combat injuries are not allocated to a separate accounting category.

At the same time, the NATO Doctrine of Health Care ("AJP-4.10 Ed. C Ver. 1 Allied joint doctrine for medical support") [17] and the NATO Doctrine of Health Care Planning ("AJMedP-1 Ed. A Ver. 1 Allied joint medical planning doctrine") [18] non-combat injuries are a separate category of sanitary losses, which is taken into account when planning the medical support of troops (forces). In particular, when planning medical care, the calculation of projected losses by patients and injured is carried out according to separate coefficients.

Imperfect and insufficient for the analysis of causal relationships is the classification of causes and circumstances of injuries, which is used in filling out the annual medical reports of military medical institutions on the form 2/Med [10]. In this regard, it is advisable to develop and implement a classification similar to the NATO standard "Statistical Classification of Diseases, Injuries and Causes of Death" (STANAG 2050 "Statistical Classification of Diseases, Injuries and Causes of Death"), which provides greater opportunities for injury analysis for the reasons of its occurrence.

The report of the Working Group on Injury Prevention of the US Armed Forces Epidemiological Administration [2] stressed the importance of introducing a trauma monitoring system and its use as a basis for developing targeted measures to prevent injuries in the military. The importance of using different standardized injury classifiers (by type of injury, by the striking cause of the injury, by the location of the injury) is emphasized, which reflects the multidimensional classification approach. At the same time, in order to avoid accounting errors due to the human factor, these classifiers should have a minimized content sufficient to analyze the phenomenon of injuries in military teams. Thus, according to the analysis of medical accounting systems, foreign researchers state that in a fairly large proportion of cases of codification of injuries, the requirements of STANAG 2050 were ignored. This may have been due to the excessive scope of this classification and the ambiguity in the interpretation of individual classification headings. Therefore, the use of approaches (implementation) of STANAG 2050 should be carried out carefully (with national notes and deviations), taking into account the existing system of medical accounting and reporting in the Armed Forces of Ukraine.

The classification of circumstances and causes of injuries, which was used in domestic accounting documents of the medical service had its evolutionary development. It was based on the principle of distribution of losses according to the circumstances and causes of their occurrence, ie indicated the general type of activity in which the injury occurred, and the reasons for their occurrence.

Their analysis shows that domestic classifications of injuries were presented in the form of two-dimensional matrices of circumstances and causes of injuries and characterized injuries only from a general standpoint, without emphasizing the variety of striking effects on which prevention work should focus on injury prevention.

It should be noted that currently the analysis of injuries in the medical service of the Armed Forces of Ukraine is conducted only once a year on the basis of generalization and processing of reports of medical reports of military units (military authorities) on form 2/Med.

That is, the improvement of the system of medical accounting and reporting in terms of injury monitoring should include: the importance of processing reporting documents; the possibility of developing proposals for the prevention of injuries in the military, based on new principles of classification of injuries; feedback with accountables in order to ensure the correctness and completeness of accounting, control over the implementation of measures to prevent injuries, as well as possible hereditary correction of classification approaches.

Based on the statistical material analyzed by us, the prevalence of pathological conditions belonging to the XIX class of diseases according to ICD-10 in the structure of hospitalizations to health care facilities of the Armed Forces of Ukraine in the area of JFO (ATO) is convincingly shown.

The predominance of traumatic pathology in the structure of patients treated in military hospitals stationed in the area of JFO (ATO) necessitates the improvement of medical and diagnostic equipment of these institutions.

To this end, the norms of supply of medical equipment of military mobile hospitals [7] introduced a mobile surgical room based on the KRAZ car and a mobile X-ray diagnostic complex based on a car with a digital $X$-ray machine (mobile $X$-ray room on the basis of the KRAZ car) which are admitted to operation in Armed Forces of Ukraine by order of the Ministry of Defense of Ukraine dated 27.03.2017 № 179 [6].

In addition, in our opinion, it is advisable to strengthen the diagnostic capabilities of military mobile hospitals through mobile computed tomography systems and mobile surgical modules, for example, on 2 operating tables, etc.

In general, based on the above study, it can be stated that the provision of medical care to patients with injuries 
and poisonings was and remains one of the highest priorities of the medical service of the Armed Forces of Ukraine in the area of JFO (ATO), even under ceasefire.

\section{Conclusions}

1. According to the results of the study, it was established that in the structure of servicemen of the Armed Forces of Ukraine treated in health care facilities of the Armed Forces of Ukraine stationed in the area of JFO (ATO), the leading place (1st place in 2015-2019 and 2 place in 2020) is the share of patients with diagnoses belonging to the XIX class of ICD-10 "Injuries, poisoning and some other consequences of external causes" (35.39 \% in 2015, 27.39 $\%$ in $2016,26.44 \%$ in $2017,22.55 \%$ in $2018,17.12 \%$ in 2019 and $16.06 \%$ in 2020), which is significantly larger than the share of similar patients in other health care facilities of the Armed Forces of Ukraine as a whole.

2. The predominance in the structure of servicemen of the Armed Forces of Ukraine treated in health care facilities

\section{References}

[1] Antomonov, M.Yu. (2018). Математическая обработка и анализ медико-биологических данных. 2-е изд. [Mathematical processing and analysis of biomedical data. 2nd ed.]. К.: МИЦ "Мединформ", 2018 - К.: MІC "Medinform", 2018.

[2] Armed Forces. (1996). Injures in the military. A hidden epidemic. A report for the Armed Forces Epidemiological Board, November 1996. The Injury Prevention and Control Work Group of the Armed Forces Epidemiological Board.

[3] Halushka, A. N., Khalik, S. V., Shvets, A. V., \& Rychka, O. V. (2019). Аналіз травматизму серед військовослужбовців Збройних Сил України в умовах повсякденної діяльності та зоні збройного конфлікту протягом останніх років [Analysis of injuries among servicemen of the Armed Forces of Ukraine in the conditions of daily activities and the zone of armed conflict in recent years]. Військова медицина Українu - Ukrainian Journal of Military Medicine, 19(2), 5-16.

[4] Khomenko, I. P. (2018). Інформаційно-аналітичні матеріали щодо результатів діяльності медичної служби Збройних Сил України в 2017 році [Information and analytical materials on the results of the medical service of the Armed Forces of Ukraine in 2017]. УВМА, НДІ ПВМ, Київ - UVМА, Research Institute of PVM, Kyiv.

[5] Ministry of Defence Ukraine. (2001). Про затвердження Taбеля термінових донесень з медичної служби (№ 7) [About the statement of the Table of urgent reports from medical service (№ 7)]. Директива Начальника Генерального штабу Збройних Сил України № ДГШ-11 від 17 грудня 2001 року. Міністерство оборони України. К., 2001 - Directive of the Chief of the General Staff of the Armed Forces of Ukraine № DGS-11 of December 17, 2001. Ministry of Defence Ukraine. K., 2001.

[6] Ministry of Defence Ukraine. (2017). Про допуск до експлуатації в Збройних Силах України кабінету рухомого рентгенівського на базі автомобіля КрАЗ та кабінету рухомого хірургічного на базі автомобіля КрАЗ [About the admission to operation in the Armed Forces of Ukraine of a mobile $X$-ray room on the basis of the KrAZ car and a mobile surgical room on the basis of the KrAZ car]. Наказ Міністерства оборони України від 27.03.2017 № 179 - Order of the of the Armed Forces of Ukraine in the area of JFO (ATO), the share of patients diagnosed with class XIX diseases ICD10 in particular due to high non-combat injuries (noncombat injuries share in the structure of hospitalized amounted to $17.36 \%$ in $2017,11.38 \%$ in $2018,9.13 \%$ in 2019 and $7.99 \%$ in 2020).

3. Determining the features of the structure of servicemen treated in health care facilities of the Armed Forces of Ukraine in the area of JFO (ATO), necessitate improvement of the system of medical accounting and reporting in the Armed Forces of Ukraine, in particular taking into account the experience of medical accounting and reporting in the NATO Armed Forces, as well as a basis for clarifying the profiling of the bed stock, amendments to supply standards, staffs and tables to the staffs of health facilities (including military mobile hospitals) concerning the quantitative and qualitative improvement of medical equipment and property intended for the treatment of patients with surgical and traumatological profile.

Ministry of Defense of Ukraine dated March 27, 2017 № 179. Access mode: http://www.mil.gov.ua/content/mou_orders/ 179_nm_2017.pdf

[7] Ministry of Defence Ukraine. (2017). Про затвердження норм постачання медичним майном військових мобільних госпіталів [About the statement of norms of supply of medical property of military mobile hospitals]. Наказ Директора Військово-медичного департаменту Міністерства оборони України від 03.11.2017 № 18. Міністерство оборони України. К., 2017 - Order of the Director of the Military Medical Department of the Ministry of Defense of Ukraine dated 03.11.2017 № 18. Ministry of Defense of Ukraine. K., 2017.

[8] Ministry of Defence Ukraine. (2019). Методичний посібник щодо класифрікації та обліку втрат особового складу Збройних Сил України, затверджений начальником Генерального штабу - Головнокомандувачем Збройних Сил України 29.10.2019 [Methodical manual on classification and accounting of losses of personnel of the Armed Forces of Ukraine, approved by the Chief of the General Staff Commander-in-Chief of the Armed Forces of Ukraine 10/29/ 2019]. Міністерство оборони України. К., 2019 - Ministry of Defence Ukraine. K., 2019.

[9] Ministry of Defence Ukraine. (2019). Настанова з медичного забезпечення Збройних Сил України на особливий період [Guidelines for medical support of the Armed Forces of Ukraine for a special period]. Наказ Генерального штабу Збройних Сил України від 11.02.2019 № 60. ГШ ЗС України. К., 2019 - Order of the General Staff of the Armed Forces of Ukraine dated 11.02.2019 № 60. General Staff of the Armed Forces of Ukraine. K., 2019.

[10] Ministry of Defence Ukraine. (2020). Наказ командувача Медичних сил Збройних Сил України від 15.05.2020 № 74 [Order of the Commander of the Medical Forces of the Armed Forces of Ukraine from 15.05.2020 № 74]. КМС ЗС України. K., 2020 - KMS of the Armed Forces of Ukraine. K., 2020.

[11] Ministry of Health of Ukraine. (2015). Показники здоров'я населення та використання ресурсів охорони здоров'я в Україні (загальний) [Indicators of population health and use of health resources in Ukraine (general)]. Центр медичної статистики МОЗ України- Center for Medical Statistics 
of the Ministry of Health of Ukraine. Access mode: http:// medstat.gov.ua/im/upload/Zagaln2015.zip

[12] Ministry of Health of Ukraine. (2016). Показники здоров'я населення та використання ресурсів охорони здоров'я в Україні (загальний) [Indicators of public health and use of health resources in Ukraine (general)]. Центр медичної статистики МОЗ України - Center for Medical Statistics of the Ministry of Health of Ukraine. Access mode: http:// medstat.gov.ua/im/upload/Zagaln2016.zip

[13] Ministry of Health of Ukraine. (2017). Показники здоров'я населення та використання ресурсів охорони здоров'я в Україні (загальний) [Indicators of public health and use of health resources in Ukraine (general)]. Центр медичної статистики МОЗ України - Center for Medical Statistics of the Ministry of Health of Ukraine. Access mode: http:// medstat.gov.ua/im/upload/Zagaln2017.zip

[14] Ministry of Health of Ukraine. (2018). Показники здоров'я населення та використання ресурсів охорони здоров'я в Україні (загальний) [Indicators of public health and use of health resources in Ukraine (general)]. Центр медичної статистики МОЗ України - Center for Medical Statistics of the Ministry of Health of Ukraine. Access mode: http:// medstat.gov.ua/im/upload/Zagaln2018.zip

[15] Ministry of Health of Ukraine. (2019). Показники здоров'я населення та використання ресурсів охорони здоров'я в Україні (загальний) [Indicators of public health and use of health resources in Ukraine (general)]. Центр медичної статистики МОЗ України - Center for Medical Statistics of the
Ministry of Health of Ukraine. Access mode: http:// medstat.gov.ua/im/upload/DOV_1_ZAG-2019.zip

[16] Ministry of Health of Ukraine. (2020). Показники здоров'я населення та використання ресурсів охорони здоров'я в Україні (загальний) [Indicators of public health and use of health resources in Ukraine (general)]. Центр медичної статистики МОЗ України - Center for Medical Statistics of the Ministry of Health of Ukraine. Access mode: http:// medstat.gov.ua/im/upload/DOV_1_ZAG-2020.zip

[17] NATO Standardization database. (2015). STANAG 2228 Ed: 4 / AJP-4.10 Ed. C Ver. 1 Allied joint doctrine for medical support. NATO Standardization database. Access mode: https:// nso.nato.int/nso/zPublic/ap/PROM/AJP 4.10\%20EDC $\% 20$ V1\%20E.pdf

[18] NATO Standardization database. (2018). STANAG 2542 Ed: 2 / AJMedP-1 Ed. A Ver. 1 Allied joint medical planning doctrine. NATO Standardization database. Access mode: https:// nso.nato.int/nso/zPublic/ap/PROM/AJMedP 1\%20EDA\%20V1\%20E.pdf

[19] Rychka, O. V., \& Lopin, Ye. B. (2019). Аналіз травматизму серед військовослужбовців в зоні проведення операції об'єднаних сил [Analysis of injuries among servicemen in the area of the joint force operation]. Проблеми військової охорони здоров'я: Зб. наук. праць Української військовомедичної академії - Problems of military health care: Collection of scientific works of the Ukrainian Military Medical Academy, 52, 257-263. 